DOI: 10.17516/1997-1370-0695

УДК 811’221.24

\title{
Specific Features and Patterns of Conceptualizing the Emotions and Feelings in Sign Language (the Case of the Regional Variant of the Russian Sign Language in the Republic of Khakassia)
}

\author{
Oksana V. Magirovskaya, Ekaterina S. Privalikhina \\ and Violetta S. Srmikian* \\ Siberian Federal University \\ Krasnoyarsk, Russian Federation
}

Received 01.02.2020, received in revised form 05.11.2020, accepted 11.12.2020

\begin{abstract}
The article presents a cognitive view on sign language. It is the first to analyze the sign language in the Republic of Khakassia, one of the regional variants of the Russian sign language which requires serious scientific research, detailed linguistic analysis and, as a further step, its official documentation. The article describes the specific features of sign conceptualization as conceptualization by a special semiotic system that functions as a language of communication for a social group of deaf people and people with hearing impairment. The key patterns of conceptualizing the emotions and feelings are specified; the basic pattern of conceptualization is claimed. The revealed specificity of conceptualizing the category of emotions and feelings in the sign language in Khakassia raises the issue of an urgent need for further research of both this regional variant of the Russian sign language and other regional variants of the Russian Federation. This, in turn, will favour the linguistic descriptions of sign language and the use of these descriptions to solve many issues related to successful social adaptation of deaf people and people with hearing impairment.
\end{abstract}

Keywords: sign, sign language, sign conceptualization, patterns of sign conceptualization of emotions and feelings, sign language in Khakassia.

This research is supported by the Russian Foundation for Basic Research (RFBR), Grant No. 20-012-00321 "Regional sign languages: multimodal electronic corpus (the case of the communicative space of Eastern Siberia)".

Research area: philology.

\footnotetext{
(C) Siberian Federal University. All rights reserved

* Corresponding author E-mail address: priv-aytak@mail.ru, magirovskayaov@yandex.ru, srm.vi94@gmail.com ORCID: 0000-0003-4286-2613 (Magirovskaya); 0000-0003-3850-5963 (Privalikhina); 0000-0002-2728-9444 (Srmikian)
} 
Citation: Magirovskaya, O.V., Privalikhina, E.S., Srmikian, V.S. (2020). Specific features and patterns of conceptualizing the emotions and feelings in sign language (the case of the regional variant of the Russian sign language in the Republic of Khakassia). J. Sib. Fed. Univ. Humanit. Soc. Sci., 13(12), 1927-1936. DOI: 10.17516/1997-1370-0695.

\section{Introduction}

It is for a long period of time - the entire $20^{\text {th }}$ century and the beginning of the $21^{\text {st }}$ century - that the scientific community showed no deep research interest to sign languages. Only a narrow circle of experts in the field of defectology and deaf and dumb pedagogy published their works of a descriptive and accumulative nature. These works formed the basis for later research on sign languages. Among them was Vygotsky's conception. It manifested a complex nature of sign language, its status as a full-fledged language system, a language of deaf children's thinking and higher mental activity. The conception did not receive proper coverage in the $30 \mathrm{~s}$ of the $20^{\text {th }}$ century. Yet, it could have become a breakthrough for Soviet linguistics. On the contrary, the communist party had a completely different view on the problem. Deaf people were considered abnormal and tongueless people, and their manual language was "not even a substitute for the language" (Zajceva, 2006: 22); at schools teachers played the role of overseers, forbidding the use of signs and forcing the deaf to communicate orally (Zajceva, 2006: 22). As a consequence, "it (the Russian Sign Language - the authors' note) was not recognized as a full-fledged means of communication and its importance in the formation of mental skills and identity of the deaf was ignored" (Kulikova, Shatokhina, 2020).

All this led to a gap between the development of the problem abroad and in Russia. In the $60 \mathrm{~s}$ of the $20^{\text {th }}$ century, W. Stokoe, an American linguist, wrote a number of works on the American Sign Language (Ref. to (Stokoe, 1960), for example). He marked the recognition of this language as an autonomous semiotic code and justified the fact that it is this language that is the most analyzed and described among other national sign languages.

Up to the 80 s of the $20^{\text {th }}$ century, in Russian state education system children with hearing impairments were taught on the basis of a verbal method that prevented from revealing deaf students' mental potential. It is at that time when the inconsistency of this approach became clear. Currently, the teachers are adopting their foreign colleagues' practice and starting to introduce the techniques of "bilingual learning" that favourably contribute to the effective development of deaf children's cognitive abilities (Zajceva, 2006: 23).

The works in Russian deaf and dumb pedagogy got their proper recognition only in 2012 when the Russian Sign Language was given its official status by the Federal Law of 2012 (FZ, 2012). Such legal recognition has become a positive factor in the sign language development, since it has led to a literary norm and a regulated curriculum formation as well as the emergence of certain specialized programmes in higher education (Shatokhina, 2019: 113).

Sign language is not a universal language of communication for all deaf people and people with hearing impairments in the world. Like spoken languages, sign languages are of a national character. The researchers tend to focus on American, Australian, and Western European sign languages mainly. In their works they have proved that sign languages not only vary from country to country, but also have a strong regional variability within one country. For example, it is revealed that the British Sign Language has a large number of variants depending on the region. This fact is explained by the geographical location of the leading educational institutions for deaf children (Quinn, 2010). According to Kimmelman (2014), the sign language in the Netherlands is characterized by a higher lexical variability than the Russian Sign Language.

The data on the number of deaf people and people with hearing impairments, provided by numerous statistical sources, differ significantly. According to the figures stated, in Russia the number of those who are involved in the sign language culture and use their sign language varies from 300 thousand to 13 million 
people with various types of hearing impairments. Health professionals state that the deaf community is growing all over the world (Varinova, 2020: 45).

This research is aimed at identifying the regional dialects of the Russian sign language. We proceed from the following main theoretical proposition underlying the research: similar to the Russian spoken language, the Russian Sign Language has a distinct regional variability. Yet, regarding the variants of the Russian Sign Language, we claim a deeper degree of regional differences compared to the Russian spoken language. It is mainly due to the lack of a centralized state translation into the Russian Sign Language on television, as well as isolation and social withdrawal of the deaf community in Russia. The differences are also caused by the country's vast territory and, as a result, a significant remoteness of the communities of deaf people and people with hearing impairment from each other. All this largely determines the dialectal features, which, in their turn, highlight the need for a thorough description of the entire map of the variants of the Russian Sign Language and for active registration of sign dialects to ensure their detailed socio-linguistic analysis.

The focus of this article is on a variant of the Russian Sign Language in the Republic of Khakassia, one of the largest regions of Eastern Siberia.

\section{The Sign Language}

in the Republic of Khakassia:

Specific Features of Localization

Eastern Siberia occupies one fourth of the territory of the Russian Federation. This is an Asian part of the country. It includes the Krasnoyarsk Krai, the Republic of Tyva, the Republic of Sakha (Yakutia), the Irkutsk Oblast, the Zabaykalsky Krai, the Republic of Buryatia, and the Republic of Khakassia.

The Republic of Khakassia borders on the Krasnoyarsk Krai in the north and in the east, with the Republic of Tyva and the Republic of Altai in the south, and with the Kemerovo Oblast in the west. The territory of the republic is $61,569 \mathrm{~km}^{2}$. The national composition of the republic is heterogeneous. This is reflected in the languages spoken on its territory. The state languages are Russian and Khakass. The Shor language is widely spoken in a number of its districts. Along with the spoken languages, sign language is also in use in Khakassia. Institutionally, this language is a language that functions in a number of educational organizations (mainly the boarding schools for deaf children and children with hearing impairments). In a broader context, it is a language of all deaf people and people with hearing impairments in Khakassia.

The undertaken research has shown that the sign language spoken in Khakassia is a regional variant of the Russian Sign Language. It has a number of features that distinguish it both from the main (Moscow) variant and from other variants of the Russian Sign Language.

\section{Research Methodology and Empirical Material}

The research methodology involves several stages.

The first (initial) stage is that of developing a glossary to compile the list of the main lexical units representing various categories which are basic ones for a human's perception of the world, his/her orientation in it, and his/her successful life (for example, time and space, natural phenomena, flora and fauna, social environment, household items, etc.).

The second stage - the stage of collecting the empirical material - was that of searching for the signers, establishing contact with them, and video registration of the signs for the lexical units from the compiled glossary. The total number of the signs recorded is over 700 .

The third (research) stage is the stage of the linguistic analysis proper. The main method applied to the analysis of signs is that of conceptual analysis. It involves the description of each registered sign, the search and justification of the basis for the conceptualization of knowledge represented by this sign, and, finally, the systematization of the revealed patterns of conceptualization.

This article describes the result of the analysis of 41 signs, representing the emotions and feelings in the sign language used in Khakassia. In the course of the analysis we have 
revealed three main patterns of conceptualizing the above mentioned category as a category that captures the humans' relatively stable mental states and their attitude to the world around them. Moreover, the results obtained confirm the authors' theoretical assumption on the selectivity of the sign coding system, its dependence on the characteristic features of the signers' perception of the world limited due to their inability to hear (Magirovskaya, Privalikhina, 2019; Magirovskaya, 2020).

\section{Methods of Conceptualizing the Category of Emotions and Feelings in the Sign Language in Khakassia}

The research considers sign conceptualization as a process of accumulation of incoming information about the world and subsequent knowledge representation for its further exchange in certain communicative acts through sign language.

In the course of conceptualization of emotions and feelings in the Khakass variant of the Russian Sign Language three patterns of knowledge formation have been distinguished. These are:

1) conceptualization based on the inner experience of emotions and feelings (32 signs);

2) conceptualization based on the orientation of emotions and feelings toward the subject / object (5 signs);

3) conceptualization based on the physical manifestation of emotions and feelings (4 signs).

\section{Conceptualization Based \\ on the Inner Experience of Emotions and Feelings}

Conceptualization based on the inner experience of emotions and feelings is the dominant pattern of perceiving and construal of these concepts in the Khakass variant of the Russian Sign Language. It is based on understanding of the emotions and feelings as the internal states of the soul. Thus, it focuses on emotional values and internal emotional processes.

For example, the concept of nenavist' (hatred) in the sign language in Khakassia is represented as a growing feeling that a human experiences within him/herself. The sign that captures this feeling is two-handed. It is performed in the centre of the chest. The hands need to be brought into the $C$-configuration, the palm looking at the chest. The hands make one movement from the bottom up, the fingertips touching the chest. The depth of perception of this feeling can be traced in the performance of the sign at the chest, which is traditionally associated with the place of the human soul.

In the Dictionary of the Russian Language (Ozhegov: URL), nenavist' is defined as a negative feeling, echoing anger, a feeling of rivalry (a feeling of strong enmity, anger). Unlike the verbal lexical unit, the nenavist' sign does not explicitly manifest any of the conceptual characteristics that underlie the verbal representation of this feeling. Accordingly, regarding the manner of performing the sign, it is possible to reveal a new conceptual feature of this feeling, which in its sign representation is focused on the development of the feeling, its certain growth, and increase. Consequently, motivation of the sign lies not in understanding this feeling as that of the opponents' opposition and their struggle, but as a feeling of inflamed inner hatred with a human's chest being the place of concentration of deep worldview.

In the culture of Khakassia, it is rejection that serves the leading vector of sign conceptualization of resentment. The execution of the obida (resentment) sign requires the $L$-configuration of the hand with the fingers up. The fingers are relaxed and slightly bent; the palm is turned with its left edge to the signer's face. The sign is performed in space in front of the face and is one-handed. The hand makes a quick short swing from bottom to top in a diagonal, approximately from the lower part of the forehead and below to the chin. The nature of the feeling itself is manifested by the sign's sharpness.

In verbal language this concept is nominated by such nouns as ogorchenie (grief), oskorblenie (insult). At the same time, the dictionary definitions emphasize that these feelings are inflicted undeservedly (unfairly caused grief, insult, and also the feeling caused by them). Comparison of the dictionary definition and the nature of the sign execution serves a jus- 
tification for stating the discrepancy between verbal and sign conceptualization. In the sign language they use in Khakassia, obida is conceptualized as a short-term feeling. Moreover, it is not a deep feeling for the Khakass signers. This is evidenced by the location of the sign at the face. All the features mentioned make it possible to interpret the sign for obida as a desire to isolate oneself, to close oneself from what causes the feeling of resentment.

Thus, the pattern of conceptualization based on the internal manifestation of emotional experiences in the Khakass variant of the Russian Sign Language is the leading one for quite a number of signs. In addition to those analyzed above, 32 more signs represent this pattern of conceptualization. They are ustalost' (fatigue), liubov' (love), nadezhda (hope), pechal' (sadness), grust' (grief), strakh (fear), udovol'stvie (pleasure), udivlenie (surprise), razdrazhenie (irritation), vozbuzhdenie (excitement), nenavist' (hatred), zhalost' (pity), radost' (joy), gnev' (anger), ugryzeniia sovesti (remorse), gordost' (pride), styd (shame), vesel'e (fun), trevoga (anxiety), vliublennost' (falling in love), doverie (trust), skuka (boredom), smekh (laughter), shok (shock), chuvstvo dolga (a sense of duty), nedoumenie (bewilderment), smushchenie (embarrassment), voskhishchenie (admiration), spokoistvie (calmness), zlost' (anger), schast'e (happiness). 6 signs out of 32 in this group are accompanied with facial expressions.

\section{Conceptualization Based on the Orientation of Emotions and Feelings toward the Subject / Object}

In the Khakass variant of the Russian Sign Language, the pattern of sign conceptualization based on the orientation of emotions / feelings toward the subject / object is less frequent. This pattern is actualized to indicate the direction of emotions and feelings from or to an object. The signs, which are based on this pattern of conceptualization, include, for example, the signs for blagodarnost' (gratitude), vina (guilt), otvrashchenie (disgust), nedovol'stvo (discontent), zavist' (envy).

The conceptual characteristic feature the feeling of blagodarnost' (gratitude) is based upon is that of great respect. The sign is a two-handed symmetrical one. It is performed in front of a signer, his/her palms touching each other and the edges of the palms touching the chest. In this position, the arms bend slightly forward, and so does a signer's body.

In the dictionary entry the concept of blagodarnost' is associated with such concepts as appreciation and kindness. If a human appreciates the service provided to him/her or any kind of attention shown to him/her, he/she is grateful for this (a feeling of gratitude for the good (Ushakov: URL)). Dictionary definitions of the nouns that nominate the feelings of gratitude and appreciation are almost mirror images of each other.

On the contrary, the sign for blagodarnost' is interpreted differently from the dictionary word representing this concept. The sign is performed in such a way as if there was a second participant in the act of communication toward whom a feeling of gratitude is directed. This conceptual meaning is manifested by a tilt of the body and arms in the direction to the intended interlocutor. The dictionary entry, in its turn, does not indicate the presence of the one who has done any good. The benefactor is not meant at all. Therefore, the revealed difference indicates the fact of profiling a new characteristic feature of this feeling in the system of sign conceptualization.

The pattern of sign conceptualization based on the orientation of emotions and feelings from a subject to an object or a second participant in the act of communication is inherent for 3 more signs: otvrashchenie (disgust), nedovol'stvo (discontent), zavist' (envy).

The subgroup of signs based on the orientation of emotions / feelings toward the subject from the outside includes only one sign out of 41. This sign is vina (guilt). The manner in which it is performed conceptualizes guilt as something that is always associated with a human who is or feels guilty. The sign involves one hand only. The hand is brought into the configuration of figure 1 . The index finger first points at the chest, then goes into $B$-configuration, the open palm is put on the signer's chest.

Dictionary entries define this concept in different ways. One of the definitions indicates 
the aspects of its legal perception (misdemeanor, crime (Ozhegov: URL)), other ones state the ability to be responsible for one's own actions to be the main conceptual characteristic feature (responsibility for a committed misconduct (Bol'shoi tolkovyi slovar': URL)). Regarding the feeling of responsibility, it is defined as punishment for what a human has done (responsibility for the consequences of actions taken; the possibility of being punished for poor results from any activity (Bol'shoi tolkovyi slovar': URL)). The sign for vina (guilt) is quite explicit in its motivation for a non-signer. It does not imply any context for its representation. The sign is focused toward a signer even if he/she demonstrates the sign for the lexical item vina only (without the context of an affirmative statement "I am guilty", for example).

Thus, the analysis has proved that such sign conceptualization is non-typical for emotions and feelings in the sign language used in Khakassia. Yet, the feeling of guilt in the Khakass variant of the Russian Sign Language is conceptualized according to the pattern based on the orientation of emotions and feelings toward an object from the outside. The basic conceptual characteristic feature of the concept derives from understanding of guilt as a punishment that a human him/herself will bear alone, the characteristic being not dominant in verbal conceptualization in dictionary entries.

\section{Conceptualization Based on the Physical Manifestation of eEmotions and Feelings}

The pattern of sign conceptualization based on physical manifestation of emotions and feelings (along with the one based on orientation of emotions and feelings toward the subject / object) is less common than conceptualization based on the inner experience of emotions and feelings. This pattern is based on the construal of a habitual action or a typical position (posture) taken by a human when he/ she experiences a certain emotion or feeling. The physical manifestation of an emotion or a feeling implies the performance of a mechanical action or interaction, as well as the position of the body (posture) typical for a particular emotion.
This pattern of sign conceptualization embraces four signs: bezrazlichie (indifference), dobrota (kindness), bol' (pain), stradanie (suffering).

Conceptualization of the feeling of indifference in the sign language used in Khakassia is based on the representation of one of a human's typical actions, denoting his/her indifference and, moreover, neglect. The sign for bezrazlichie is performed with two hands; the palms are not given any specific configuration but kept relaxed in front of the signer, opposite the chest. In this position, the signer shakes his/ her hands. At the same time, facial expressions are involved: the eyes are averted, the lips are stretched, and the corners of the lips are lowered. The movement made by the hands can be interpreted as a desire to shake hands off something (water, dirt, crumbs, etc.).

In Ozhegov's Dictionary of the Russian Language, the feeling of bezrazlichie is explained through the concepts of indifference and detachment (indifference, disinterest to someone or something (Ozhegov: URL)). Unlike the noun bezrazlichie, the sign for it represents a certain human activity performed during the moments when this emotion is experienced. So, if a human gets his/her hands dirty, he will shake them to make them clear. Yet, he/she will shake his/her hands in some distance from the body for the splashes from his/her hands not to splatter a human him/herself or others, that is in the distance where the surrounding objects are of no value to a human and, consequently, they can be soiled because of his/her indifference to them.

Thus, the sign for bezrazlichie is based on the physical representation of a peculiar action of shaking hands. Moreover, it is possible to reveal non-verbalized features of this concept in the sign language in Khakassia. The sign is more negative in its connotation. This is not a "zero" emotion as it is defined in the Dictionary of the Russian Language. It profiles the conceptual features of disgust and neglect.

Conceptualization of the feeling of dobrota (kindness) is based on profiling the conceptual characteristics of softness and tenderness. The two-handed sign consists of stroking one's own hand. To perform the sign the hands are 
located in front of the signer, they are relaxed. The palm of one hand runs over the back of the other hand once. The movement is tender, hasteless, but not slow.

Verbal representation of this concept in the dictionary indicates such conceptual characteristics of the feeling as willingness to help, a desire to do good to others, natural benevolence and sympathy towards people (responsiveness, emotional disposition towards people, a desire to do good to others (Ozhegov: URL]). The sign for dobrota profiles softness and tenderness that is manifested through the physical action of stroking. This action is usually performed by a human to stroke the objects made of a delicate material, pleasant to be touched (for example, a fabric made of silk). It is also common for stroking the animals with soft fur that is pleasant for tactile sensations. However, stroking means more than just a human's desire to touch something pleasant. It also symbolizes a human's kind, supportive attitude. For example, a person strokes another one on his/her back/shoulder/arm when consoling and calming him/her (I stroke because I am kind, because I want to help). Thus, the conceptual analysis of the sign proves that the meaning of this concept within the framework of sign conceptualization is revealed through the physical action of stroking, which is associated with the conceptual characteristic features of tenderness and softness. Moreover, the interpretation of the performance of the sign also allows one to reveal such additional properties of kindness as a desire to console and calm down.

Regarding the mentioned above, the pattern of sign conceptualization based on the physical manifestation of emotions and feelings in the Khakass variant of the Russian Sign Language serves a cognitive basis for four signs, one of which is accompanied by facial expressions. The sign for dobrota profiles a physical action of stroking. The sign for bezrazlichie represents an action of shaking hands which is typical for the representatives of the ethnic community of Khakassia. It is in this sign that facial expressions are involved: the mouth stretches in a straight line, the corners of the lips go down, and the gaze is averted. In addition, the performance of both signs reveals new characteristic features of these concepts that do not receive their verbal manifestation in dictionary definitions.

\section{Specificity of Conceptualization of the Category of Emotions and Feelings in the Sign Language in Khakassia}

The analysis of lexical signs nominating feelings and emotions in the Khakass variant of the Russian Sign Language proves the regional specificity of this semiotic system. The analysis of patterns of their conceptualization has revealed a number of differences between the verbal conceptualization of emotions and feelings and their sign conceptualization in the Khakass regional version of the Russian Sign Language.

The main difference is in the nature of the patterns of sign conceptualization of emotions and feelings singled out in the signs performed by the Khakass signers. According to the analysis, facial expressions do not serve an important element of conceptualizing this category in the sign language of Khakassia on the basis of their external manifestation. As it turned out, the representatives of the Khakass ethnic culture use facial expressions only in 7 signs out of 41 analyzed. Consequently, for this regional variant it is not scientifically justified to single out a subgroup of signs that conceptualize emotions and feelings mainly through facial expressions.

Another specific feature of sign conceptualization of emotions and feelings in the sign language in Khakassia is a similar execution of signs representing different emotions. Among the emotions and feelings that are not distinguished as different in the course of sign conceptualization are the following ones:

- liubov' (love) and vliublennost' (infatuation);

- radost' (joy), vesel'e (fun), voskhishchenie (admiration) (it is worth while noting that the signs for udovol'stvie (pleasure) and vozbuzhdenie (excitement) have a sign for $r a$ dost' (joy) as one of their components);

- udivlenie (surprise) and shok (shock) (the sign for udivlenie (surprise) is one of the 
components of the sign for vozbuzhdenie (excitement));

- ugryzeniia sovesti (remorse), gnev (anger), skuka (boredom), smushchenie (embarrassment);

- the sign for skuka (boredom) can also coincide with the sign for obida (resentment);

- the sign for stradanie (suffering) consists of the signs for pechal' (sadness) and bol' (pain);

- otvrashchenie (disgust) and nedovol'stvo (discontent).

Such a coincidence of 17 out of the 41 signs under the analysis can be interpreted as a rather distinct tendency in the Khakass signer's language to contextualize emotions and feelings. Perception and understanding of a particular sign denoting the emotions and feelings mainly depend on extra-linguistic factors of communication.

Some of the signs in the Khakass variant of the Russian Sign Language have an integral nature (for example, the signs for udovol'stvie (pleasure), vozbuzhdenie (excitement), and stradanie (suffering)). The sign for udovol'stvie (pleasure) consists of the sign for radost' (joy) which is accompanied with one-handed stroking in the centre of the chest with the palm of the hand from top to bottom, the movement being slower than the previous ones. The components of the sign for vozbuzhdenie (excitement) are the signs for radost' (joy) and udivlenie (surprise). To perform the sign for stradanie (suffering) the signer consistently performs the signs for pechal' (sadness) and bol' (pain).

A characteristic feature of conceptualization of emotions and feelings in the sign language used in Khakassia is not only the integration of signs, but, as a consequence, the integration of patterns of conceptualization. For example, the sign for zavist' (envy) results from merging of the pattern of conceptualization based on the inner experience of emotions and feelings and the pattern of conceptualization based on the orientation of emotions and feelings toward the subject/object. The sign for stradanie (suffering) reveals the merging of the pattern of conceptualization based on the inner experience of emotions and feelings and the pattern of conceptualization based on the physical manifestation of emotions and feelings.

While describing various aspects of Russian culture, Likhachev notes that "due to the Russian historical past, we, Russian people, often prefer emotional concepts to logical definitions" (Likhachev, 2000: 108). Sternin and Sternina claim that the Russians demonstrate stronger emotional behaviour in the course of communication in comparison with the Americans, for example (Sternin, Sternina, 2001). The scholars explain the main difference by the Russians' sincerity, their desire to talk from heart to heart, and to discuss personal experiences. It is most likely that a Russian person will not hide negative emotions towards his/her communicative partner - he/she is less tolerant than an American (Sternin, Sternina, 2001). The analysis of the signs of the Khakass variant of the Russian Sign Language, however, does not confirm this theoretical prerequisite about the peculiarities of the emotional component of verbal communication, since facial expressions are often used to represent negative and positive emotions in the performance of the signs under the analysis.

In the course of the research it was not only possible to identify the conceptual characteristic feature(s) motivating the signs. The analyzed bulk of signs has proved that at the present stage of linguistic research of sign conceptualization (which is currently quite a new field of scientific knowledge) the decoding of signs for emotions and feelings (happiness, hope, a sense of duty, etc.) in the Khakass variant of the Russian Sign Language still causes a certain difficulty. The prospects of further detailed conceptual analysis are also in identification of a whole set of conceptual characteristics, since most of the considered signs represent conceptual characteristics of particular emotions and feelings which are not found in the dictionary entries defining the nouns that nominate the units of this category in the Russian verbal language.

The analysis has also revealed that the sign conceptualization of emotions and feelings is most often based on the inner experience of these emotions and feelings by a human: most signs are performed in front of a signer, near 
his/her chest; the performance is not characterized by explicitness and iconicity. This refutes the view on the sign language as a secondary and non-developed system for knowledge representation and proves its equal semiotic status with the verbal language.

\section{Conclusion}

Sign languages require the linguists' serious attention and thorough analysis. It is primarily due to the fact that sign languages are autonomous unique mechanisms for rendering the meanings in the process of communication. Moreover, sign languages are equally original as tools for representing the concepts of the real world. The study of the characteristic features of conceptualization peculiar for the sign languages and the identification of main patterns and schemes of this cognitive process are valuable both for demarginalization of sign languages and their users and for understanding the cognitive mechanisms of human thinking.
The research on the peculiar features of conceptualizing the emotions and feelings in the regional variant of the Russian Sign Language that functions in the Republic of Khakassia proves that the sign nomination of emotions and feelings is clearly manifested in the choice of the pattern and conceptual basis for coding the knowledge about them. For the considered regional variant, the key pattern of forming the knowledge about emotions and feelings is conceptualization based on the inner experience of emotions and feelings. It is this pattern that is activated for perception and cognition of this category.

The semantic capacity of the sign semiotic system of knowledge representation indicates its "high potential for coding the information about the world" (Privalikhina, 2019: 295) and highlights the urgency of its detailed research in terms of deep analysis of both national sign languages and their regional variants.

\section{References}

FZ (2013). Federal'nyi zakon № 296-FZ ot 30 dekabria 2012 g. "O vnesenii izmenenii v stat'i 14 i 19 Federal'nogo zakona "O sotsial'noi zashchite invalidov v Rossiiskoi Federatsii" [Federal Law No. 296-FZ of December 30, 2012 "On Amendments to Articles 14 and 19 of the Federal Law "On Social Protection of Disabled People in the Russian Federation"] [Electronic resource]. In Rossiiskaia Gazeta, 3. Available at: https://rg.ru/2013/01/11/invalidi-dok.html (Accessed September 15, 2020).

Kimmelman, V. (2014). Information structure in Russian Sign Language and Sign Language of the Netherlands: Doctoral dissertation, Amsterdam Center for Language and Communication. Digital Academic Repository, 267 p.

Kulikova, L.V., Shatokhina, S.A. (2020). Sociocultural and Linguistic Contexts of the Russian Sign Language Functioning in Krasnoyarsk Krai. In J. Sib. Fed. Univ. Humanit. Soc. Sci., 13(3), 296-303.

Kuznetsov, S.A. Bol'shoi tolkovyi slovar' russkogo iazyka [The Large Explanatory Dictionary of the Russian Language] [Electronic resource]. Available at: https://gufo.me/dict/kuznetsov (Accessed September 22, 2020).

Likhachev, D.S. (2000). Russkaia kul'tura [Russian culture]. Moscow, Iskusstvo, 440 p.

Magirovskaya, O.V. (2020). Zhestovyi iazyk kak osobaia sistema kontseptualizatsii znanii [Sign language as a system of knowledge conceptualization]. In Cognitive Studies of Language, Vol. 3(42), 155-160.

Magirovskaya, O.V., Privalikhina, E.S. (2019). The Lexical Level of Sign Language as a Specific System of Nomination (The Case of American and Russian Languages). In Mir Nauki, Kul'tury, Obrazovaniya, 4(77), 389-391.

Ozhegov, S.I. Tolkovyi slovar' russkogo iazyka [Dictionary of the Russian Language] [Electronic resource]. Available at: https://slovarozhegova.ru/ (Accessed September 22, 2020).

Privalikhina, E.S. (2019). Conceptual studies of sign language: challenges and prospects. In Cognitive Studies of Language, XXXVII, 293-297.

Quinn, G. (2010). Schoolization: An Account of the Origins of Regional Variation in British Sign Language. In Sign Language Studies, 10(4), 476-501. 
Shatokhina, S.A. (2019). Trends of development of sign languages. In Kazanskaya nauka, 7, 111-114.

Sternin, I.A., Sternina, M.A. (2001). Ocherk amerikanskogo kommunikativnogo povedeniia [Essay on American Communication Behavior]. Voronezh, Voronezh State University, 206 p.

Stokoe, W.C. (1960). Sign Language Structure: An Outline of the Visual Communication Systems of the American Deaf, In Studies in Linguistics. In Occasional Papers, 8, 1-78.

Ushakov, D.N. Tolkovyi slovar' russkogo iazyka [The Explanatory Dictionary of the Russian Language] [Electronic resource]. Available at: https://ushakovdictionary.ru/ (Accessed September 22, 2020).

Varinova, O.A. (2020). Osobennosti opisaniia sotsial'nogo soobshchestva glikhikh liudei [Features of the description of the social community of deaf people]. In Theory and practice of social development, 7(149), 44-48.

Zajceva, G.L. (2006). Dialogue with L.S. Vygotsky on the problems of modern surdopedagogy. In Cultural-Historical Psychology, 3, 21-27.

\title{
Специфика и способы концептуализации эмоций и чувств в жестовом языке (на материале регионального варианта русского жестового языка Республики Хакасия)
}

\author{
О.В. Магировская, Е.С. Привалихина, В.С. Срмикян \\ Сибирский федеральныий университет \\ Российская Федераџия, Красноярск
}

\begin{abstract}
Аннотация. Статья выполнена в аспекте когнитивных исследований жестового языка. В ней впервые рассматривается жестовый язык Республики Хакасия, который является одним из региональных вариантов русского жестового языка, требующих серьезного научного внимания, детального лингвистического анализа и, как следствие, официальной документации. В статье описывается специфика жестовой концептуализации как концептуализации в рамках особой семиотической системы, функционирующей как язык общения социальной группы глухих и слабослышащих людей. Анализируются основные выявленные способы концептуализации эмоций и чувств, обосновывается ведущий способ концептуализации. Описанная специфика концептуализации категории «эмоции и чувства» в жестовом языке Хакасии ставит вопрос необходимости дальнейшего изучения как данного регионального варианта русского жестового языка, так и других региональных вариантов. Это, в свою очередь, позволит описать жестовый язык в научном аспекте и использовать данные описания для решения многих вопросов, связанных с успешной социальной адаптацией глухих и слабослышащих людей, выработкой нормы национального жестового языка и др.
\end{abstract}

Ключевые слова: жест, жестовый язык, жестовая концептуализация, способ жестовой концептуализации эмоций и чувств, жестовый язык Хакасии.

Исследование выполнено в рамках гранта РФФИ № 20-012-00321 «Региональные жестовые языки: мультимодальный электронный корпус (на материале коммуникативного пространства Восточной Сибири)».

Научная специальность: 10.00.00 - филологические науки. 